\title{
Avoiding the Water-Poverty Trap: Insights from a Conceptual Human- Water Dynamical Model for Coastal Bangladesh
}

Edoardo Borgomeo $^{1 *}$, Jim W. Hall ${ }^{1}$, Mashfiqus Salehin ${ }^{2}$

1. Environmental Change Institute, University of Oxford, Oxford, UK.

2. Institute of Water and Flood Management, Bangladesh University of Engineering and Technology, Dhaka, Bangladesh.

*Corresponding author: Edoardo Borgomeo, Environmental Change Institute, South Parks Road, Oxford, OX1 3QY, Oxford, UK, + 441865275848 


\title{
Avoiding the Water-Poverty Trap: Insights from a Conceptual Human- Water Dynamical Model for Coastal Bangladesh
}

\begin{abstract}
Water-related risks impact development opportunities and can trap communities in a downward spiral of economic decline. In this paper, the dynamic relationship between waterrelated risks and economic outcomes for an embanked area in coastal Bangladesh is conceptualized. The interaction between flood events, salinity, deteriorating and poorly maintained water infrastructure, agricultural production and income is modelled. The model is used to test the effect of improvements in the reliability, operation and maintenance of the water infrastructure on agricultural incomes and assets. Results indicate that interventions can have non-marginal impacts on indicators of welfare, switching the system dynamic from a poverty trap into one of growth.
\end{abstract}

Keywords: Bangladesh, salinity, coupled human-water systems, system dynamics, poverty, water security 


\section{Introduction}

Empirical analyses of hydro-climatic variability and economic output (measured as GDP) have shown that hydrological variability and water-related disasters, such as floods and droughts, have a statistically significant effect on economic growth in many countries, (e.g., Brown and Lall, 2006; Brown, Meeks, Hunu and Yu., 2011; Brown, Meeks, Ghile and Hunu, 2013). Recent work by Sadoff et al. (2015) highlighted the global economic impact of water insecurity.

At the micro level, empirical evidence suggests that environmental shocks, including those related to water, play a significant role in compromising the potential for economic development and in perpetuating poverty (Carter, Little, Mogues and Negatu., 2007; Dercon and Christiaensen, 2011). Recent natural disasters in South Asia (e.g., typhoon Hayan and cyclone Alia) are also a reminder of the increasing vulnerability and exposure of poor populations to water-related shocks (Barbier, 2014) and the potential for climate change to seriously compromise poverty reduction efforts (Hallegatte et al., 2016).

Although empirical analyses have shown the impact of water on economic growth, there remains a lack of understanding of (i) how multiple water-related hazards aggregate within coupled human-natural systems to influence overall economic activity, potential for economic development and poverty reduction and (ii) how alternative water security interventions (e.g., investments in water infrastructure or water management institutions) influence the dynamics of these coupled systems and contribute to poverty reduction efforts. This understanding is crucial to inform the appraisal of water security interventions, which needs to be based on the quantification of the dynamical response of complex coupled human-water systems to sequences of interventions over time.

Nonetheless, economic appraisal of the benefits of interventions in water systems (e.g., through irrigation, drainage, flood protection or provision of safe drinking water supplies and 
sanitation) typically takes a marginal approach, quantifying the direct impacts in terms of increased agricultural production, reduced risks of flooding or infant mortality or time saved in collecting water (Hutton, 2013). This bottom-up approach does not deal with the distributional effects of water-related risks, in particular for the poorest in society, nor does it consider the non-marginal effect that improvements in water security might have on the dynamics of growth at community and regional scales. Focusing on these non-marginal effects and on the human-water system dynamics helps to better understand and model the persistence of water-related risks and interventions in the economy and their long-term effects on economic activities and investment planning (for an application to the economic costs of climate change see Estrada, Tol and Gay-Garcia (2015)).

This focus on the dynamics between human activities and the water environment is at the core of the International Association of Hydrological Sciences Scientific Decade on 'Change in Hydrology and Society' (Montanari et al., 2013), which calls for improved understanding and prediction of coupled human-water systems. A similar focus is also emerging in the development literature, where there is increasing recognition that appraisals of development and poverty reduction interventions need to account for the complex nonlinear dynamics underlying coupled human-natural systems and their inherent uncertainty (Ramalingam, 2013; Hallegatte et al., 2016).

A range of established (e.g., Coupled Human and Natural System (Liu et al., 2007); system dynamics (Mirchi, Madani, Watkins and Ahmad, 2013)) and emerging (e.g., socio-hydrology (Sivapalan, Savenije and Blöschl, 2012)) interdisciplinary frameworks have been applied to study and model the dynamics of coupled human-water systems. Di Baldassarre, Kooy, Kemerink and Brandimarte (2013) and following studies (Viglione et al., 2014; Di Baldassarre et al., 2015) modelled flood risk as a dynamical function of flood events, collective memory and societal decisions on resettlement or investment in flood protection. 
The framework developed by Di Baldassarre et al. (2013) was extended by Grames, Prskawetz, Grass, Viglione and Blöschl (2015) to develop a theoretical model of flood occurrence and economic growth. Giuliani, Castelletti and Gandolfi (2016) simulated adaptation decision-making in irrigated agriculture and in the context of urban water systems, whilst Garcia, Portney and Islam (2016) developed a socio-hydrological model to compare alternative reservoir operating polices based on the interaction between reliability and demand growth.

In the context of water, poverty and the economy, system dynamics approaches have been used to model small holder farmer systems in Maharastra (India) under changing hydrological and economic conditions (Pande and Savenije, 2016), the theoretical relationships between water and trade (Dang et al., 2016), natural resource-based poverty traps in Kenya (Stephens et al., 2012) and the relationship between economic growth, infectious diseases and poverty traps (Ngonghala et al., 2014). For more comprehensive reviews of recent studies on coupled human-water systems the reader is referred to Troy, Konar, Srinivasan and Thompson (2015a), O’Donnell and O'Connell (2016), and Blair and Buytaert (2016).

This study adopts a coupled human-water system dynamics approach to conceptualise and model flooding of agricultural land, soil salinity, farmers' incomes and deteriorating and poorly maintained water infrastructure in embanked areas in coastal Bangladesh. The aim of this study is to understand and model the dynamical interaction between water-related hazards, agricultural-dependent livelihoods and water policy interventions in coastal areas undergoing environmental change. In particular, this study's objectives are to (i) examine the effects of soil salinity and flooding on the persistent poverty of farmers and the extent to which these water-related hazards reinforce a water- poverty trap and (ii) simulate the nonmarginal effects that improvements in reliability, operation and maintenance of water 
infrastructure have on the dynamics of poverty and growth. The model presented here, similar to other coupled human-water models (e.g., Di Baldassarre et al., 2015), is conceptual and exploratory, though it is inspired by the challenging and very dynamic situation in coastal Bangladesh and incorporates realistic parameters defined using secondary data. The model should be interpreted as a tool to learn about the system in question, inform future model development, monitoring and data collection.

The paper proceeds by introducing the context for the case study and providing a detailed explanation of the coupled human-water system model in Section 2. The results of the model are presented in Section 3. In Section 4 results are discussed and emphasis is placed on future model improvements and priorities for data collection. Section 5 presents the conclusions.

\section{Case Study System}

\section{Water and Poverty Dynamics in Coastal Bangladesh}

The manifestations of water and poverty dynamics in coastal Bangladesh are multiple and include lack of access to safe drinking water sources and sanitation facilities, pollution and high exposure to water-related disasters (Ahmad, 2003). This paper focuses on issues related to flooding and salinity and their impact on poverty in embanked areas in coastal Bangladesh.

The low-lying areas in the Ganges-Brahmaputra tidal delta plain were embanked in the 1960s and 1970s to protect communities from tidal flooding and boost agricultural productivity and food security (Nowreen, Jalal and Khan, 2014). Drainage channels and sluice gates were constructed inside these embanked areas, known with the Dutch term 'polders', to regulate freshwater flows (Zaman, 1983). Despite the increased food production afforded by these interventions, the 8 million people living in the coastal polders are still vulnerable to waterrelated hazards and poverty remains extreme (Tuong et al., 2014). Furthermore, the current status of poor management and deterioration of the flood protection and drainage 
infrastructure (Thompson and Sultana, 1996) will be exacerbated by the long-run effects of sea level rise and erosion (Payo et al., 2016), salinity intrusion (Hussain, Islam, Hossain and Hoque, 2012; Hoque et al., 2016) and the projected intensification of cyclone-related storm surges (Dasgupta et al., 2014a).

In response to this situation, a large number of initiatives are being planned and implemented to reduce coastal communities' vulnerability to water-related hazards, to improve well-being and economic welfare and to create opportunities for economic development. Examples include the Coastal Embankment Improvement Project (World Bank, 2013), the BlueGold project (BlueGold, 2012), UNICEF's Managed Aquifer Recharge programme (UNICEF, 2014) and the Bangladesh Delta Plan (General Economic Division, 2014).

An improved understanding of the water- poverty dynamics and the role that alternative interventions have in altering these dynamics has the potential to inform these ongoing initiatives and future water-related investments in the area. The impacts of water and especially climate-related risks on livelihoods in coastal Bangladesh have been examined in several studies (e.g., Shameem, Momtaz and Rauscher (2014); Toufique and Islam (2014); Ahsan and Warner (2014); Hossain (2015)). Recent work by Mutahara, Haque, Alam Khan, Warner and Wester (2016) developed a novel framework to investigate the livelihood security of coastal communities exposed to storm surge hazard. A focus on livelihoods is also at the centre of Bernier, Sultana, Bell and Ringler (2016)'s work examining the role of agriculture and irrigation infrastructure on well-being and livelihood strategies in coastal Bangladesh. Work by Szabo et al. (2016) tested the impact of soil salinity and household socio-economic characteristics on food security in coastal Bangladesh. Nicholls et al. (2016) used a novel integrated assessment model to analyse the dynamics between ecosystem services and livelihoods in the Ganges-Brahmaputra-Meghna Delta within Bangladesh. Di Baldassarre, Yan, Ferdus and Brandimarte (2014) studied the interplay between human 
population dynamics and flooding at the country-level. The approach presented in this paper differs in that the dynamics between agricultural incomes, water-related hazards and water infrastructure are conceptualized at the scale of an individual polder.

To conceptualize these dynamics, a stylized system model of an embanked area in coastal Bangladesh is developed. Data from the academic literature and a recent survey (Bangladesh Water Development Board, 2012) is used to guide model formulation and parameterization. The Bangladesh Water Development Board (2012) survey identified a range of water-related issues that negatively influence livelihoods in the coastal polders, including soil salinity, flooding, deteriorating embankments, drainage congestion due to a lack of system operation and maintenance. The model is built to examine and understand changes in agriculture-based incomes in response to these water-related variables.

The schematic diagram in Figure 1 depicts the major state variables and interactions considered in this dynamical model and builds on theoretical models of poverty-environment traps in coastal areas (Barbier, 2015). Soil salinity limits crop growth, which is also affected by other environmental limiting factors. In the dynamical model, the levels of soil salinity vary seasonally and depend on the state of the water infrastructure and the level of saline water intrusion. In reality, soil salinity is influenced by a number of other factors including rainfall, evaporation and depth of the groundwater table which are not considered in this model.

Periodic floods inundate part or all of the area available for agriculture, causing abrupt losses in agricultural yields and incomes. Different types of floods occur in coastal Bangladesh, including river floods, tidal floods and storm surge floods due to tropical cyclones (Rahman and Salehin, 2013). In the model the occurrence of storm surge floods due to tropical cyclones and the subsequent reduction in the area available for productive agriculture are 
simulated. The frequency and magnitude of these flood events are parameterized and can be changed to simulate increased frequency and magnitude of flooding as a result of climate change.

Soil salinity, flooding and decaying water infrastructure - which includes the flood protection as well as the drainage infrastructure- all negatively impact agricultural production. This declining agricultural production leads to declining incomes and assets. Household assets also suffer periodic shocks due to flooding, reinforcing what is called here the water-poverty trap. The model is employed to explore these water- poverty dynamics and their response to interventions, modelled as improvements in the water infrastructure which may result from collective action dedicated to the operation and maintenance of the infrastructure or engineering measures to rehabilitate existing structures.

[Figure 1 here]

The state variables and interactions depicted in Figure 1 are encoded in a series of equations described in detail in the following section. These equations are based on relationships proposed in the literature (e.g., the flood occurrence) and/or simple conceptual formulations of natural or socio-economic processes. The simulation model is developed and run on a monthly time step to account for the seasonality in salinity levels.

The lack of data and the stylized nature of the equations mean that it is impossible to validate this model in a traditional sense, nonetheless general figures from government surveys are adopted to sense-check the results. These equations can be considered as working hypotheses of the relationships between different components of the system (Troy, Pavao-Zuckerman and Evans, 2015b). As noted by Sivapalan and Blöschl (2015), the impossibility of validating the model in a traditional sense does not limit its usefulness in terms of exploring 
system dynamics, further the general understanding of the processes and inform future model development.

\section{Model Components}

Agriculture

Agricultural production is the central element of the model, as it links water-related hazards to well-being metrics based on incomes and asset accumulation. Agricultural production $P$ is modelled for a typical small farm in Bangladesh (Table 1). This amount of land is taken to be the maximum area available for cultivation in the farm, and then it is subject to flooding according to the relationship specified in Section 2.2.2 below.

\section{[Table 1 here]}

The income and water security dynamics for the landless are not modelled explicitly, though it should be noted that they will be influenced by salinity and flooding because job and income opportunities for landless wage labourers are expected to decrease when fewer land is available for agriculture.

The area available for agricultural production $A$ at each time step $t$ in the simulation is a function of the total area $A_{T}$ available for cultivation and the flooded area $A_{F}$ as explained in section 2.2.2. Agricultural yields in the polder will depend on this area $A$ and also on a range of factors, including soil salinity, temperature, labour and fertilizer use amongst others. In this stylized model, agricultural yields are estimated as a function of soil salinity levels $s_{L}$ and an environmental stress parameter $e_{F}$ (e.g., Cho and Oki, 2012). This environmental stress parameter is not impacted by the polder system's characteristics nor by the water security interventions and is thus held constant throughout the simulation. This parameter could be equally expressed as a time-dependent stochastic function of rainfall, temperature data, atmospheric $\mathrm{CO}_{2}$ concentrations and other environmental variables which affect crop growth and yield. 
To estimate the yield under changing salinity conditions, the analysis starts by identifying a value of the average yield $\bar{Y}_{x}$ per hectare for a specific crop $x$ in the coastal area of Bangladesh, shown in Table 2 (Bangladesh Water Development Board, 2012). This is the yield obtained when environmental conditions are favourable to crop growth. Then the actual yield $Y_{x}$ is determined, that is, the yield a hypothetical farmer would get after limiting factors, such as salinity $s_{L}$ and other environmental stresses $e_{F}$, are taken into account:

$Y_{x}(t)=\bar{Y}_{x}(t)-\bar{Y}_{x}(t) \cdot \min \left(\left(s_{L}(t)+e_{F}\right), 1\right)$

The estimated actual yield per hectare can then be combined with the total area available for agricultural production $A_{x}$ for each crop $x$ to determine total production $P$ for each crop $x$.

Table 2 presents the percentage of the area allocated to each crop and the crop calendar in the hypothetical farm (i.e. time of the year when crops are grown), determined using data from Bangladesh Water Development Board (2012). According to this distribution, paddy cultivars account for $69 \%$ of the cultivated area, with the remaining $31 \%$ used for non-paddy crops (grass pea, vegetables). The crop calendar is used to limit production for each crop to the time period specified in Bangladesh Water Development Board (2012). The model does not simulate the different stages of crop growth, so the relationship between growth stage, plant response to different stresses (e.g., salinity, flooding) and harvest at the end of the crop year cannot be explicitly modelled. To obtain a first order approximation of the impact of different stresses on agricultural production, agricultural production $P$ is assumed to correspond to the minimum yield obtained during the crop calendar interval $\left(c_{1}, c_{2}\right)$ :

$$
P_{x}(t)=\min _{c_{1} \leq t \leq c_{2}}\left(Y_{x}(t) \cdot A_{x}(t)\right)
$$

The agricultural income $\pi$ for the household at the end of each year $n$ is a function of the actual yields for each crop type and the crop prices indicated in Table 2 (BBS, 2013): 


$$
\pi(n)=\left[\sum_{x=1}^{10} p_{x} \cdot P_{x}(t)\right] \quad \mid \quad t \in n
$$

Crop prices can vary with time, but they are assumed to be constant here for simplicity.

[Table 2 here]

\section{Flood occurrence}

Flood occurrence is modelled as a marked point Poisson process where flood events occur uniformly at random with an average waiting time $\lambda$ with a magnitude $F$ (Viglione et al., 2014). On average a severe cyclone strikes Bangladesh every three years (MOEF, 2009), so for the baseline simulations the waiting time $\lambda$ is set to $1 / 36$ (given the model's monthly time step). The flood magnitude $F$ is sampled from a beta distribution with parameters 1 and 1.4. The fraction of land area $A_{F}$ flooded during an event is a function of the magnitude of the event $F$, the reliability of the water infrastructure $e_{R}$ and a damage parameter $\gamma$ :

$$
A_{F}(t)=\left\{\begin{array}{cc}
\frac{A_{T}}{\gamma \cdot e_{R}(t)} \cdot F^{3}(\tau) & \text { if } t=\tau \\
0 & \text { otherwise }
\end{array}\right.
$$

where $0 \leq A_{F} \leq A_{T}, \tau$ is the time of occurrence of a flood and the value of $\gamma$ has been set to 5.

The flood waters retreat following an exponential decay function, which assumes that the flooded area is completely recovered after 6 months. This flood water retreat function determines the area available for cultivation $A$ at any time $t$ during the simulation:

$$
A(\mathrm{t})=\left\{\begin{array}{cc}
A_{T}-A_{F}(t) \cdot e^{-\frac{\tau-t}{5}} & \text { if } \tau<t<\tau+5 \\
A_{T} & \text { otherwise }
\end{array}\right.
$$

The exponent of the exponential decay function can be changed to simulate cases where the retreat of flood waters takes more than 6 months, causing water-logging and longer periods of reduced agricultural production. 


\section{Salinity}

Soil salinity in Bangladesh is a time-dependent process with a minimum typically observed during the monsoon season (June to October), when rainfall washes off salinity from the soils. As freshwater availability decreases, soil salinity levels increase from November onwards, with maximum levels during March and April. The soil salinity data presented in Lázár et al. (2015) is used to define a soil salinity profile $s_{p}$ which defines 'background' salinity conditions. In reality, the impact of soil salinity on crops will also depend on the type of crop and on the crop growth stage. Given the conceptual nature of the model presented here and the lack of field data on soil salinity, information on salinity tolerance was not included in the model.

Soil salinity is also a function of an intrusion parameter $q$ which controls the level of saline water intrusion due to external stresses (e.g., sea level rise or shrimp farming expansion (Karim, 2006)). This parameter can be used to explore the sensitivity of agricultural production to increases in salinity, which negatively impacts livelihoods in the area also by compromising drinking water quality (Khan et al., 2011; Rabbani, Rahman and Minuddin, 2013; Shameem, Momtaz and Rauscher, 2014; Dasgupta, Huq and Wheeler, 2015). The intrusion parameter $q$ can be constrained by referring to projections of salinity increases in the area (for example Dasgupta et al., (2014b)). Salinity levels are also a function of the reliability, operation and maintenance of the water infrastructure which regulates freshwater and saltwater flows in and out of the polder:

$$
s_{L}(t)=\frac{q}{\min \left(e_{R}(t), 1\right)} \cdot s_{p}(t)
$$

\section{Water Infrastructure Reliability, Operation and Maintenance}

A time dependent deterioration process is used to model the changing reliability, operation and maintenance of the polder's water infrastructure (e.g., Buijs, Hall, Sayers and van Gelder, 2009). This variable ranges from 0 (no flood protection and poor state of the internal water drainage systems) to 1 (maximum flood protection level and regular operation and 
maintenance). The water infrastructure $e_{R}$ is assumed to deteriorate at a rate $d_{e}$. The water infrastructure is also affected by potential interventions $I_{e}$ which can increase its reliability, operation and maintenance over a time interval $t_{s}$ and $t_{e}$ :

$e_{R}(t)=\left\{\begin{array}{cc}e_{R}(t-1)-d_{e} \cdot e_{R}(t-1)-D(t)+I_{e} & \text { if } t_{s} \leq t \leq t_{e} \\ e_{R}(t-1)-d_{e} \cdot e_{R}(t-1)-D(t) & \text { otherwise }\end{array}\right.$

where $0 \leq I \leq 1-e_{R}(t-1)$ and $0 \leq e_{R}(t) \leq 1$. Although the type of interventions to improve the water infrastructure are not specified, they may comprise single or multiple measures, such as heightening of the embankment crest, foreshore afforestation to reduce the hydraulic load on the embankments during a storm, regular cleaning of the drainage canals or strengthening of institutional arrangements for the maintenance of water diversion and sluice gates (e.g., Dewan, Mukherji and Buisson, 2015). Deterioration of the water infrastructure may result when local communities or governments fail to carry out routine maintenance work or are not properly involved in project planning and operation (Thompson and Sultana, 1996). Lack of maintenance of the water infrastructure can be intentional to allow for brackish water flow in shrimp farms (Paprocki and Cons, 2014).

The water infrastructure experiences a damage $D$ during storms, as for instance reported by Islam, Bala, Hussain, Hossain and Rahman (2011) following Cyclone Sidr, which is proportional to the magnitude $F$ of the flood event in question:

$D(t)=\left\{\begin{array}{cc}\frac{F(\tau)}{\beta} & \text { if } t=\tau \\ 0 & \text { otherwise }\end{array}\right.$

where $\beta$ is the water infrastructure damage parameter which has been set to 20 . 


\section{Incomes}

Income in any year of the simulation equals to the agricultural income $\pi(n)$, which is taken here to be the only income generating activity. Other income generating activities, such as labour sale and fishing are not considered in the model.

The agricultural income estimated with equation (3) is compared to the income figures (Table 2) for rural households with similar size of land holding presented in Bangladesh's Household Income and Expenditure Survey (BBS, 2010) to appraise the model's ability at reproducing reasonable agricultural income estimates for the area.

A saving fraction $\varphi$ of the income generated via agricultural activities contributes to the assets $K$. These assets build over time and enable the households to deal with unforeseen expenses, such as losses incurred due to flooding. The evolution of the asset stock is a function of a depreciation rate $\delta$, income $\pi$, and expenditure $L$ incurred following a flood-related shock. The asset for each year $n$ in the simulation is:

$K(n)=\left\{\begin{array}{cc}\varphi \cdot \pi(n)+\delta K(n-1)-L(t) & t \in n \\ \varphi \cdot \pi(n)+\delta K(n-1) & \text { otherwise }\end{array}\right.$

where $L$ is the extra expenditure incurred to deal with a flood. $L$ is inversely proportional to the farmer's ability to save:

$L(n)=\left\{\begin{array}{cc}\frac{\left(\frac{A_{F}}{A_{T}}\right)}{(1+\varphi)^{2}} K(n-1) & \text { if } \tau \in n \\ 0 & \text { otherwise }\end{array}\right.$

This only allows for asset accumulation trajectories related to agricultural production to be examined. Field work is underway to identify how assets are actually accumulated (human capital, improvements in housing) (e.g., Barrett et al., 2013) and inform future model development. Preliminary results indicate that poor households do not accumulate any 
financial assets, a finding which is consistent with previous studies on asset-based poverty traps in Bangladesh (Quisumbing and Baulch, 2013). The impact of floods on agricultural production means that these households are able to afford less food so risk becoming malnourished, leading to a serious decline in well-being. For these households, it is helpful to think of this economic metric of assets as representing a multi-dimensional level of household well-being. The model parameters and state variables and associated definitions are summarised in Table 3.

[Table 3 here]

\section{Results}

\section{Simulating the Water-Poverty Trap}

A water-poverty trap materializes when agricultural production is negatively influenced by increasing flood damage and salinity levels. To explore this dynamic, environmental parameters (flood events, saline water intrusion and environmental stress parameters) are kept constant during this simulation, which is used to understand system dynamics under conditions with no environmental change.

The results of the simulation are presented in Figure 2, which shows (from top to bottom) the time series of flood peaks, the fraction of area flooded, the soil salinity levels, the water infrastructure reliability and the annual income for a small landowner. Under rapidly deteriorating water infrastructure and lack of maintenance, a declining income due to declining agricultural yields can be observed. The decline in income is driven by the lack of maintenance of the water infrastructure, or a 'non-cooperative' water system dynamic (Madani, 2010), which leads to a 'tragedy of the commons' type of outcome where the lack of institutions and incentives to operate and maintain the water infrastructure lead to 
increasing soil salinity, increasing flood damage and subsequently decreasing agricultural production and declining incomes.

[Figure 2 here]

Figure 3 shows how flood events cause sudden drops in income levels and restrict households' ability to accumulate assets, undermining the ability of small landowners to invest. The simulated income profile in Figure 3 is well aligned with income statistics for small landowners in rural Bangladesh shown in Table 1 (BBS, 2010). Differences between model results and national income statistics might be due to the fact that this model considers agriculture as the only income generating activity and that crop prices are assumed to be constant at 2013 levels.

[Figure 3 here]

To examine the asset dynamics under deteriorating water infrastructure, a poverty trap graph depicting the asset evolution was generated (Figure 4). In Figure 4, the 45-deg line shows a stable situation (no accumulation, no loss). If the point is below the 45-deg line, the asset going forward is lower than the asset from the previous year, implying a 'poverty trap' mechanism, if the point is above the line, then there is asset accumulation (i.e., no poverty trap).

The left panel in Figure 4 shows how assets $\mathrm{K}_{\mathrm{t}+1}$ for the hypothetical farmers eventually endup below the 45-deg line (lower part of Figure 4, for assets less than 1000 tk). This dynamic leads to a 'water- poverty trap' whereby assets at future time-steps are lower than assets at antecedent time-steps. This limits the potential for investment and economic development. Figure 4 also shows the periodic drops in the asset variable due to extra expenditures incurred following a flood. 
[Figure 4 here]

\section{Effects of Improvements in the Reliability, Operation and Maintenance of Water Infrastructure}

This section shows the effect of improvements in the reliability, operation and maintenance of the water infrastructure on the income and asset accumulation dynamics. The environmental parameters (salinity intrusion, flood events, environmental stress factors) were held constant in this simulation (values in Table 3) and the initial values for the water infrastructure variable were set to 0.4 to represent the present-day deteriorating system. This value was selected to reflect field evidence showing the poor state of the embankment (World Bank, 2013). This should not be interpreted as an actual assessment of the current reliability of the embankment, rather it should be viewed as a way of testing the model's behaviour under a scenario of low reliability, operation and maintenance of the water infrastructure.

The improvements are assumed to occur simultaneously following a period of rapid deterioration and lack of maintenance. Figure 5 shows the evolution of the system variables over time in response to the improvements in the reliability, operation and maintenance of the water infrastructure. The water security interventions and the lack of further deterioration lead to a drop in soil salinity levels and a significant reduction of the area flooded following flood events.

[Figure 5 here]

These improvements are reflected in higher agricultural yields and also more stable incomes for the farmer (Figure 6). In this instance, the hypothetical farmer is able to accumulate assets over time. This asset accumulation is reflected in Figure 7, showing how the asset values remain steadily above the 45-deg line. Under this scenario, the farmer is still susceptible to 
asset losses due to flood events; however, the losses are considerably smaller than the ones suffered under the status quo simulations presented in Figure 4.

\section{[Figure 6 here]}

The asset dynamics plot (Figure 7) shows how improvements in water infrastructure reliability, operation and maintenance can help small landowners escape the poverty trap, thus avoiding a situation where declining incomes and assets perpetuate poverty. In this case study, the focus is on policy interventions directly related to water and their effects on poverty; however, other types of interventions, including access to loans, subsidies and markets could contribute towards improved well-being of communities in the coastal area of Bangladesh.

[Figure 7 here]

\section{Discussion}

The conceptual model presented in this study should not be viewed as an attempt to accurately model water and poverty dynamics in embanked areas in coastal Bangladesh, but as a proof-of-concept to (i) demonstrate how the impact of multiple water-related hazards and water security interventions on human welfare metrics can be modeled and quantified, (ii) generate insight into possible system trajectories and (iii) guide future model development and data collection. As with any system model, boundaries were drawn around the system, so have significant factors that traverse those boundaries have been excluded. These factors include the multiple water influences upon human well-being and development in the coastal zone in Bangladesh, such as access to reliable and affordable drinking water supplies and adequate sanitation facilities and groundwater utilization for irrigation (Pal, Adeloye, Babel 
and Das Gupta, 2011). Moreover, as with other emerging models of coupled human-water systems, parameterization of this model is based on preliminary estimates and validation is limited by lack of longitudinal empirical evidence (Gober and Wheater, 2015).

The stylized nature of the conceptual model begs the question of the type of data that could be used to support future developments and parameterizations. A non-exhaustive list of possible data sources that could be used to improve the conceptual model is presented in Table 4. Improved understanding of the impact of water-related variables on human welfare metrics could be acquired via traditional survey methods, such as focus group discussion (e.g., Penning-Rowsell, Sultana and Thompson, 2011) or semi-structured interviews (Nasreen, Hossain and Azad, 2013; Azad and Khan, 2015), or unconventional techniques to collect socio-economic data such as financial diaries (Collins, Morduch, Rutherford and Ruthven, 2009). High-resolution nightlight data could be used to estimate flood damages (Ceola, Laio and Montanari, 2015, Kocornik-Mina, McDermott, Michaels and Rauch, 2015; Gomez, Di Baldassarre, Rodhe and Pohjola, 2015), whilst mobile-based technologies could be used to map population movement in response to flood events (Lu et al., 2016). Mobile based technologies could also be used to obtain rainfall (e.g., Overeem, Leijnse and Uijlenhoet, 2013) and groundwater level data (Colchester, Greeff, Thomson, Hope and Clifton, 2014; Colchester, Marais, Thomson, Hope and Clifton, 2017) to constrain the environmental stress factor parameter in the model. Information on river dynamics and flows (Turner and Richter, 2011), responsible for river bank erosion, and phytoplankton bloom dynamics (Castilla et al., 2015), responsible for poor water quality and endemic cholera in Bangladesh (Islam et al., 2015), could be obtained from citizen scientists (Buytaert et al., 2014) and added to the system model to simulate the impacts of poor drinking water quality on human welfare.

[Table 4 here] 
Alongside improvements in data sources, several components of the model could be upgraded by incorporating more physically based representations of biophysical processes. For instance, the approach developed by Mondal et al. (2015) to simulate rice yield in response to different levels of salinity could inform the agricultural component of the model. Similarly, higher resolution models of soil salinity dynamics under multiple land uses, climate conditions and sea-level rise scenarios could provide better estimates of salinity levels, especially if combined with hydrodynamic models as in Payo et al. (2017). Field data on soil salinity and crop tolerance could also provide more realistic estimates to constrain simulated crop yields. Improved representation of salinity processes could also allow for modelling of the impacts of flood events on salinity, as in some instances flooding may lead to reductions in salinity.

Hydrodynamic models (e.g., Karim and Mimura, 2008) could be used to simulate more accurately inundation and subsequent retreat of the flood waters and also the extent of river bank erosion at present and under different levels of flood protection (e.g., Khan, 2015). Similarly, hydrodynamic models could be used to better quantify embankment damage following a storm surge event, to dynamically model flood area and depth depending on the embankment's height and state. Sediment transport models (e.g., Mashriqui, 2003; Chen, Hsu, Shi, Raubenheimer and Elgar, 2015) can be used to assess sedimentation rates inside and outside embanked areas. This will inform assessments of the long-term implications of embankments on sediment compaction and subsidence (e.g., Auerbach et al., 2015), allowing planners to establish the need to implement sediment control techniques such as tidal river management, which involves the periodic controlled breaching and inundation of parts of the polders to allow for sedimentation (Hossain et al., 2015). Although the impacts of tidal river management have been assessed before (Khadim, Khan and Shum, 2013), they have never been considered as part of a broader framework seeking to appraise policy alternatives. 
In terms of the wider use of this and future versions of the model, it is envisaged that they will feed into a coastal zone knowledge and monitoring water security observatory where the regional implications of environmental change and water insecurity are quantified to inform water-related investments in the area (e.g., see Ray et al. (2015) and Wheater and Gober (2015) for a similar concept in a river basin). The challenge of water security requires 'placebased' science (Wheater and Gober, 2015) where monitoring, empirical data analysis and modelling are combined to quantify the response of coupled human-water systems to environmental change and adaptation interventions. Appraisal of water security interventions needs to occur within an adaptive system, and this model is a first step in the development of a water security monitoring and learning platform for coastal Bangladesh.

Uncertainty around future hydro-climatic conditions has the potential to greatly influence efforts towards water security and opportunities for economic development (Hall et al., 2014; Garrick and Hall, 2014). For water security interventions to be valuable and effective, this uncertainty needs to be characterized and accounted for in the analysis of system dynamics. Methods to account for this uncertainty in long-term water resources management decisions exist (e.g., Haasnoot, Kwakkel, Walker and ter Maat, 2013; Simpson et al., 2016; Ray and Brown., 2015); and they should be mainstreamed in the appraisal of water security interventions alongside novel models coupling the dynamics of human-water systems.

\section{Conclusions}

This paper presents a first attempt to conceptualise and simulate the water and poverty dynamics occurring in coastal systems undergoing rapid environmental change. The problem has been framed with a dynamical systems perspective to analyse the interactions between multiple water-related hazards (soil salinity and periodic flooding), agriculture-based incomes 
and interventions and maintenance of water infrastructure in embanked areas in coastal Bangladesh.

The coupled human-water system model shows how water-related hazards can substantially impact opportunities for economic and human development, leading to a water-poverty trap. The simulation study shows how interventions in water security, in the form of improved reliability, maintenance and operation of the water infrastructure, can help coastal communities escape this poverty trap.

Results indicate that interventions to improve water security can have non-marginal impacts on indicators of welfare, switching the system dynamic from one of decline (a poverty trap) into one of growth. This suggests that appraisals of investments in water security should go beyond marginal approaches, which only quantify the direct impacts on specific sectors, to account for the non-marginal effects that improvements in water security might have on growth and development dynamics at multiple, nested scales and for different actors of society.

Resources to finance water-related interventions in Bangladesh and other areas exposed to rapid environmental change are limited, therefore methods to prioritize investments to mitigate water-related risks are particularly needed. As also observed for the coastal zone of West Bengal, attempts at poverty alleviation in these exposed areas will involve a range of policy alternatives including out-migration (Sanchez-Triana, Ortolano and Paul, 2016). In the future, models driven by conceptual and theoretical understanding, such as the stylized model presented here, are going to be combined with 'Big Data' input to calibrate these models, monitor outcomes and appraise alternative policies within an adaptive learning and management approach. 


\section{Acknowledgments}

This study was supported by REACH-Improving water security for the poor. REACH is funded by the UK Department for International Development (201880). The authors would like to acknowledge discussions with Prof Rahman, Prof Mondal, Prof Nasreen, Prof Eusuf, Emily Barbour, Rob Hope and Alex Fischer and the support of Steph Ferguson in drawing Figure 1. We would also like to thank the editor and reviewer for their comments who helped to improve the paper. 


\section{References}

Ahmad, Q. (2003). Towards Poverty Alleviation: The Water Sector Perspectives.

International Journal of Water Resources Development, 19, 263-277, DOI:

$10.1080 / 0790062032000089356$

Ahsan, M. N., J., Warner (2014). The socioeconomic vulnerability index: A pragmatic approach for assessing climate change led risks-A case study in the south-western coastal Bangladesh. International Journal of Disaster Risk Reduction, 8, 32-49.

Auerbach, L. W., S. L. Goodbred Jr, D. R. Mondal, C. A. Wilson, K. R. Ahmed, K. Roy, M.

S. Steckler, C. Small, J. M. Gilligan \& B. A. Ackerly (2015). Flood risk of natural and embanked landscapes on the Ganges-Brahmaputra tidal delta plain. Nature Climate Change, $5,153-157$.

Azad, A.K. and M., Khan (2015). Post Aila Situations as Social Pathology. International Journal of Sociology and Anthropology, 3, 85 - 94.

Bangladesh Water Development Board (2012). Water Management Review in Polder 45. Ministry of Water Resources, Dhaka, Bangladesh.

Barbier, E. (2014). A global strategy for protecting vulnerable coastal populations. Science, $345,1250-1251$.

Barbier, E. (2015). Climate change impacts on rural poverty in low-elevation coastal zones. Estuarine, Coastal and Shelf Science, 165, A1-A13.

Barrett, A., R. McIntosh, M. Pritchard, M. Hannan, Z. Alam, and M. Marks (2013). Asset Values: Why Are Some Households Doing Better than Others? Chars Livelihood Program. Dhaka, Bangladesh: CLP-2/DFID. 
BBS (2010). Report of the Household Income \& Expenditure Survey 2010. Bangladesh Bureau of Statistics (BBS) Statistics and Informatics Division, Ministry of Planning. Dhaka, Bangladesh. Available online:

BBS (2013). Yearbook of Agricultural Statistics of Bangladesh 2013. Bangladesh Bureau of Statistics (BBS) Statistics and Informatics Division, Ministry of Planning. Dhaka, Bangladesh. Available online:

Bernier, Q., P., Sultana, AR., Bell, C., Ringler (2016). Water management and livelihood choices in southwestern Bangladesh. Journal of Rural Studies, 45, 134-145.

Blair P, Buytaert W. (2016). Socio-hydrological modelling: a review asking "why, what and how?” Hydrology and Earth System Sciences, 20, 443-478

Bluegold (2012). Bluegold: Program for Integrated Sustainable Economic Development by improving the Water and Productive Sectors in selected Polders. Program Document. Dhaka, Government of Bangladesh.

Brown, C., U., Lall (2006).Water and economic development: The role of variability and a framework for resilience. Natural Resources Forum, 30, 306-317. doi: 10.1111/j.14778947.2006.00118.x

Brown, C., Meeks, R., Hunu, K., Yu, W. (2011). Hydroclimate risk to economic growth in sub-Saharan Africa. Climatic Change, 106, 621-647.

Brown, C., Meeks, R., Ghile, Y., Hunu, K. (2013). Is water security necessary? An empirical analysis of the effects of climate hazards on national-level economic growth. Phil Trans $R$ Soc A 371: 20120416. http://dx.doi.org/10.1098/rsta.2012.0416 
Buijs, F. A., Hall, J. W., Sayers, P. B., Van Gelder, P. (2009). Time-dependent reliability analysis of flood defences. Reliability Engineering and System Safety, 94, 1942-1953.

Buytaert, W., Zulkafli, Z., Grainger, S., Acosta, L., Bastiaensen, J., De Bièvre, B., Bhusal, J., Chanie, T., Clark, J., Dewulf, A., Foggin, M., Hannah, D. M., Hergarten, C., Isaeva, A., Karpouzoglou, T., Pandeya, B., Paudel, D., Sharma, K., Steenhuis, T., Tilahun, S., Zhumanova, M., and Van Hecken, G (2014). Citizen science in hydrology and water resources: opportunities for knowledge generation, ecosystem service management and sustainable development. Frontiers in Earth Science 2, 26.

\section{http://dx.doi.org/10.3389/feart.2014.00026}

Carter, M. R., P. D. Little, T. Mogues, and W. Negatu (2007). Poverty Traps and Natural Disasters in Ethiopia and Honduras. Word Dev. 35, 835-56.

Castilla, EP, Cunha, DGF, Lee, FWF, Loiselle, S., Ho, KC, Hall, C. (2015). Quantification of phytoplankton bloom dynamics by citizen scientists in urban and peri-urban environments. Environ Monit Assess 187: 690. doi:10.1007/s10661-015-4912-9

Ceola, S., F. Laio, and A. Montanari (2015). Human-impacted waters: New perspectives from global high-resolution monitoring. Water Resour. Res., 51, 7064-7079, doi:10.1002/2015WR017482.

Chen, J.-L., T.-J. Hsu, F. Shi, B. Raubenheimer, and S. Elgar (2015).Hydrodynamic and sediment transport modeling of New River Inlet (NC) under the interaction of tides and waves. J. Geophys. Res. Oceans, 120, 4028-4047, doi:10.1002/2014JC010425.

Cho, J., Oki, T. (2012). Application of temperature, water stress, $\mathrm{CO}_{2}$ in rice growth models. Rice, 5:10. doi:10.1186/1939-8433-5-10 
Colchester, F.E., Greeff, H., Thomson, P., Hope, R., Clifton, D. (2014). Smart Handpumps: a preliminary data analysis. Appropriate Healthcare Technologies for Low Resource Settings (AHT 2014), 1-4.

Colchester, F.E., Marais, H.G., Thomson, P., Hope, R., Clifton, D. (2017) Accidental infrastructure for groundwater monitoring in Africa. Environmental Modelling and Software, $91,241-250$.

Collins, D., J. Morduch, S. Rutherford, and O. Ruthven (2009). Portfolios of the Poor: How the World's Poor Live on Two Dollars a Day. Princeton, Princeton University Press.

Corke, P. et al. (2010). Environmental Wireless Sensor Networks. Proceedings of the IEEE 98, 1903-1917.

Dang, Q., M., Konar, J.J., Reimer, G., Di Baldassarre, X., Lin, R., Zeng (2016). A theoretical model of water and trade. Advances in Water Resources, 89, 32-41.

Dasgupta, S., M Huq, ZH Khan, MMZ Ahmed, N Mukherjee, MF Khan, K Pandey (2014a). Cyclones in a changing climate: the case of Bangladesh. Climate and Development, 6, 96-110.

Dasgupta, S; F. A., Kamal; Z., H., Khan; S., Choudhury; A., Nishat (2014b). River salinity and climate change : evidence from coastal Bangladesh. Policy Research working paper ; no. WPS 6817. Washington, DC: World Bank Group.

Dasgupta, S.; M., Huq; D., Wheeler (2015). Drinking water salinity and infant mortality in coastal Bangladesh. Policy Research working paper ; no. WPS 7200. Washington, DC: World Bank Group. 
Dercon, S., and L. Christiaensen (2011). Consumption Risk, Technology Adoption and Poverty Traps: Evidence from Ethiopia. J. Dev. Econ., 96, 159-73.

Dewan, C., Mukherji, A., Buisson, MC (2015). Evolution of water management in coastal Bangladesh: from temporary earthen embankments to depoliticized community-managed polders. Water Int., 40, 1-6.

Di Baldassarre, G., Kooy, M., Kemerink, J. S., and Brandimarte, L. (2013). Towards understanding the dynamic behaviour of floodplains as human-water systems, Hydrol. Earth Syst. Sci., 17, 3235-3244.

Di Baldassarre, Yan, K., Ferdus, M. R., L., Brandimarte (2014). The interplay between human population dynamics and flooding in Bangladesh: a spatial analysis. Evolving Water Resources Systems: Understanding, Predicting and Managing Water-Society Interactions Proceedings of ICWRS2014, Bologna, Italy, June 2014 (IAHS Publ. 364, 2014).

Di Baldassarre, G., A. Viglione, G. Carr, L. Kuil, K. Yan, L. Brandimarte, and G. Blöschl (2015).Debates - Perspectives on socio-hydrology: Capturing feedbacks between physical and social processes, Water Resour. Res., 51, 4770-4781, doi:10.1002/2014WR016416.

Estrada F, Tol RS, Gay-Garcia C. (2015). The persistence of shocks in GDP and the estimation of the potential economic costs of climate change. Environmental Modelling \& Software, 69, 155-165.

Garcia, M., Portney, K., Islam, S. (2016). A Question Driven Socio-Hydrological Modelling Process. Hydrology and Earth System Sciences, 20, 73-92.

Garrick, D., J.W. Hall (2014). Water security and society: risks, metrics, and pathways. Annu. Rev. Environ. Resour., 39, 611-639. 
General Economic Division (2014). Inception Report. Bangladesh Delta Plan 2100

Formulation Project. Dhaka, Planning Commission Government of Bangladesh.

Giuliani, M., Y. Li, A. Castelletti, and C. Gandolfi (2016). A coupled human-natural systems analysis of irrigated agriculture under changing climate. Water Resour. Res., 52, 6928-6947, doi:10.1002/2016WR019363.

Gober, P., and H. S. Wheater (2015). Debates-Perspectives on socio-hydrology: Modeling flood risk as a public policy problem. Water Resour. Res., 51, 4782-4788, doi:10.1002/2015WR016945.

Gomez, AJS, Di Baldassarre, G., Rodhe, A., Pohjola, VA (2015). Remotely sensed nighlights to map societal exposure to hydrometeorological hazards. Remote Sens., 7, 12380-12399; doi:10.3390/rs70912380

Grames, J., A. Prskawetz; D., Grass, A., Viglione, G., Blöschl (2015). Modelling the interaction between flooding events and economic growth, ECON WPS - Vienna University of Technology Working Papers in Economic Theory and Policy, No. 04/2015

Haasnoot, M., J. H., Kwakkel, W. E., Walker, and J., ter Maat (2013). Dynamic adaptive policy pathways: A method for crafting robust decisions for a deeply uncertain world. Glob. Environ. Change, 23, 485-498.

Hall, J.W., D. Grey, D. Garrick, F. Fung, C. Brown, S.J. Dadson, C.W. Sadoff (2014). Coping with the curse of freshwater variability. Science, 346, 429-430.

Hallegatte, S., M., Bangalore, L., Bonzanigo, M., Fay, T., Kane, U., Narloch, J., Rozenberg, D., Treguer, A., Vogt-Schilb (2016). Shock Waves : Managing the Impacts of Climate Change on Poverty. Climate Change and Development;. Washington, DC: World Bank. 
Hope, R., Foster, T., Money, A., Rouse, M. (2012). Harnessing mobile communications innovations for water security. Global Policy 3(4), 433-442.

Hoque, M.A., P. F. D. ScheelbeekP. VineisA. E. KhanK. M. AhmedA. P. Butler (2016). Drinking water vulnerability to climate change and alternatives for adaptation in coastal South and South East Asia. Climatic Change, 136, 246-263.

Hossain, M. N. (2015). Analysis of human vulnerability to cyclones and storm surges based on influencing physical and socioeconomic factors: Evidences from coastal Bangladesh. International Journal of Disaster Risk Reduction, 13, 66-75.

Hossain, F., Khan, Z. H., Shum, C. K. (2015). Tidal river management in Bangladesh. Nature Climate Change, 5, 492.

Hussain, MA, AKMS Islam, MA Hossain, MT Hoque (2012). Assessment of Salinity Distributions and Residual Currents at the Northern Bay of Bengal considering Climate Change Impacts. The International Journal of Ocean and Climate Systems, 3, (3), 173-186.

Hutton, G. (2013). Global costs and benefits of reaching universal coverage of sanitation and drinking-water supply. Journal of Water and Health, 11, 1-12.

Islam MS, Islam MS, Mahmud ZH, Cairncross S, Clemens JD, Collins AE (2015). Role of phytoplankton in maintaining endemicity and seasonality of cholera in Bangladesh. Trans $R$ Soc Trop Med Hyg. 109, (9) 572-8.

Islam, A., Bala, S., Hussain, M., Hossain, M., and Rahman, M. (2011). Performance of Coastal Structures during Cyclone Sidr. Nat. Hazards Rev., 10.1061/(ASCE)NH.15276996.0000031, 111-116. 
Karim, M.R. (2006) Brackish water shrimp cultivation threatens permanent damage to coastal agriculture in Bangladesh. In: C.T. Hoanh, T.P. Tuong, J.W. Gowing and B. Hardy (eds.) Environment and livelihoods in tropical coastal zones, pp. 61-71. CABI International, Wallingford, Oxford, UK.

Karim, MF, Mimura, N. (2008). Impacts of climate change and sea-level rise on cyclonic storm surge floods in Bangladesh. Global Environmental Change, 18, (3), 490-500.

Khadim, F. K., Kar, K.K., Halder, P.K., Rahman, M.A., Morshed, AKM (2013). Integrated Water Resources Management impacts in South West Coastal Zone of Bangladesh and FactFinding on Tidal River Management. Journal of Water Resource and Protection, 5, 953-961.

Khan, Ireson A, Kovats S, Mojumder SK, Khusru A, Rahman A, Vineis P.(2011). Drinking water salinity and maternal health in coastal Bangladesh: implications of climate change. Environmental Health Perspectives, 119, 9, 1328-1332.

Khan, M. (2015). Modeling the bank erosion of selected reach of Jamuna river. Unpublished Master of Science Thesis, Bangladesh University of Engineering and Technology. Dhaka, Bangladesh.

Kocornik-Mina, A., McDermott, TKJ, Michaels, G., Rauch, F. (2015). Flooded cities. Oxford Department of Economics Discussion Paper, Number 772.

Lázár, A.N., Clarke, D., Adams, H., Akanda, A. R., Szabo, S., Nicholls, R.J., Matthews, Z., Begum, D., Saleh, A.F.M., Abedin, A., Payo, A., Streatfield, P.K., Hutton, C.W., Mondal, M.S. and Moslehuddin , A. Z. Md. (2015). Agricultural livelihoods in coastal Bangladesh under climate and environmental change - a model framework. Environmental Science: Processes \& Impacts, 1-14. doi:10.1039/C4EM00600C. 
Liu, J. et al. (2007). Complexity of Coupled Humand and Natural Systems. Science, 317, $5844,1513-1516$.

Lu, X., Wrathall, D. J., Sundsøy, P. R., Nadiruzzaman, M., Wetter, E., Iqbal, A., ...

Bengtsson, L. (2016). Unveiling hidden migration and mobility patterns in climate stressed regions: a longitudinal study of six million anonymous mobile phone users in Bangladesh. Global Environmental Change, 38, 1-7.

Madani, K. (2010). Game theory and water resources. Journal of Hydrology, 381, 3, 225-238.

Mashriqui, H. S. (2003). Hydrodynamic and sediment transport modeling of deltaic sediment processes, Ph.D. thesis, 146 pp., Civ. and Environ. Eng., La. State Univ., Baton Rouge.

Mirchi, A., Madani, K., Watkins, D., Ahmad, S. (2012). Synthesis of system dynamics tools for holistic conceptualization of water resources problems. Water Resources Management, 26, (9), 2421-2442.

MOEF (2009). Bangladesh Climate Change Strategy and Action Plan 2009. Ministry of Environment and Forest, Dhaka, Bangladesh.

Mondal MS, Saleh AF, Razzaque Akanda MA, Biswas SK, Md Moslehuddin AZ, Zaman S, Lázár AN, Clarke D (2015). Simulating yield response of rice to salinity stress with the AquaCrop model. Environ Sci: Processes Impacts, 7, 6, 1118-26. doi: 10.1039/c5em00095e.

Montanari, A., G. Young, HHG Savenije, D Hughes, T Wagener, LL Ren, D Koutsoyiannis, Christophe Cudennec, E Toth, S Grimaldi, G Blöschl, M Sivapalan, K Beven, H Gupta, M Hipsey, B Schaefli, Berit Arheimer, E Boegh, SJ Schymanski, G Di Baldassarre, Bofu Yu, P Hubert, Y Huang, A Schumann, DA Post, V Srinivasan, C Harman, S Thompson, M Rogger, A Viglione, H McMillan, G Characklis, Z Pang, V Belyaev (2013). Pantha Rhei -Everything 
Flows: Change in hydrology and society - The IAHS Scientific Decade 2013-2022.

Hydrological Sciences Journal, 58, 6, 1256-1275.

Morrow, V., G. Crivello (2015). What is the value of qualitative longitudinal research with children and young people for international development? International Journal of Social Research Methodology, 18, 3, 267-280, DOI: 10.1080/13645579.2015.1017903

Mutahara, M., Haque, A., Alam Khan, M. S., Warner, J. F., Wester, P. (2016). Development of a sustainable livelihood security model for storm-surge hazard in the coastal areas of Bangladesh. Stoch Environ Res Risk Assess., 30, 5, 1301-1315. doi:10.1007/s00477-016$1232-8$

Nasreen, M., Hossain, K.M., Azad, M.A.K, (2013). Climate Change and Livelihood in Bangladesh: Experiences of people living in coastal regions. Proce. of Int. Con. of Building Resilience. 2013. Sri Lanka (Online). Available: http://www.buildresilience.org/2013/proceedings/files/papers/454.pdf, pp.1-25.

Ngonghala CN, Plucinski MM, Murray MB, Farmer PE, Barrett CB, et al. (2014). Poverty, Disease, and the Ecology of Complex Systems. PLoS Biol, 12(4): e1001827. doi:10.1371/journal.pbio.1001827

Nicholls, RJ, CW, Hutton, AN, Lázár, A, Allan, WN, Adger, H, Adams, J, Wolf, M, Rahman, M, Salehin (2016). Integrated assessment of social and environmental sustainability dynamics in the Ganges-Brahmaputra-Meghna delta, Bangladesh. Estuarine, Coastal and Shelf Science, 183, 370-381 http://dx.doi.org/10.1016/j.ecss.2016.08.017. 
Nowreen, S., M. Rashed Jalal, and M. S. A. Khan. (2014). Historical analysis of rationalizing South West coastal polders of Bangladesh. Water Policy, 16, 264-269.

http://dx.doi.org/10.2166/wp.2013.172

O’Connel, P. E., O’Donnel, G. (2014). Towards modelling flood protection investment as a coupled human and natural system. Hydrol. Earth Syst. Sci., 18, 155-171.

O'Donnell, G and O'Connell, PE. (2016). Human-Hydrology System Modeling. In: VP Singh (Ed) Chow's Handbook of Applied Hydrology, Second Edition, Chapter 10, pp151.1 - 151.12, McGraw-Hill Education.

Overeem, A., Leijnse, H., Uijlenhoet, R. (2013). Country-wide rainfall maps from cellular communication networks. PNAS, 110, 8, 2741-2745.

Pal, SK, Adebayo J. Adeloye, Mukand S. Babel \& Ashim Das Gupta (2011). Evaluation of the Effectiveness of Water Management Policies in Bangladesh, International Journal of Water Resources Development, 27, 401-417.

Pande, S., and H. H. G. Savenije (2016). A sociohydrological model for smallholder farmers in Maharashtra, India, Water Resour. Res., 52, doi:10.1002/2015WR017841.

Paprocki, K. and Jason Cons (2014). Life in a shrimp zone: aqua- and other cultures of Bangladesh's coastal landscape, The Journal of Peasant Studies, 41, 1109-1130. DOI: $10.1080 / 03066150.2014 .937709$

Payo, A., Mukhopadhyay, A., Hazra, S. et al. (2016). Projected changes in area of the Sundarban mangrove forest in Bangladesh due to SLR by 2100, Climatic Change 139: 279. doi:10.1007/s10584-016-1769-z 
Payo, A., Lázár, A. N., Clarke, D., Nicholls, R. J., Bricheno, L., Mashfiqus, S. and Haque, A. (2017), Modelling daily soil salinity dynamics in response to agricultural and environmental changes in coastal Bangladesh. Earth's Future. Accepted Author Manuscript. doi:10.1002/2016EF000530

Penning-Rowsell, E. C., Sultana, P., \& Thompson, P. M. (2013). The 'last resort'? Population movement in response to climate-related hazards in Bangladesh. Environmental Science and Policy, 27, S44-S59. doi:10.1016/j.envsci.2012.03.009

Quisumbing AR, Baulch B. (2013). Assets and poverty traps in rural Bangladesh. Journal of Development Studies. 49, 7, 898-916

Rabanni, G., Rahman, A. and Minuddin, K. (2013). Salinity-induced loss and damage to farming households in coastal Bangladesh. International Journal of Global Warming, 5, 400415.

Rahman, R, M, Salehin (2013). Floods risks and reduction approaches in Bangladesh. In Shaw, R. et al (eds.) Disaster Risk Reduction Approaches in Bangladesh, Disaster Risk Reduction, Springer Japan.

Ramalingam, B. (2013). Aid on the edge of chaos. Oxford, Oxford University Press.

Ray, P. A., Yang, Y. E., Wi, S., Khalil, A., Chatikavanij, V., Brown, C. (2015). Room for improvement: hydroclimatic challenges to poverty-reducing development of the Bramaphutra River basin. Environmental Science \& Policy, 54, 64-80.

Ray, Patrick A.; Brown, Casey M., (2015) Confronting Climate Uncertainty in Water Resources Planning and Project Design : The Decision Tree Framework. Washington, DC: World Bank. 
Richey, A. S., B. F. Thomas, M.-H. Lo, J. T. Reager, J. S. Famiglietti, K. Voss, S. Swenson, and M. Rodell (2015). Quantifying renewable groundwater stress with GRACE, Water Resour. Res., 51, 5217-5238, doi:10.1002/2015WR017349.

Sadoff, C.W., Hall, J.W., Grey, D., Aerts, J.C.J.H., Ait-Kadi, M., Brown, C., Cox, A., Dadson, S., Garrick, D., Kelman, J., McCornick, P., Ringler, C., Rosegrant, M., Whittington, D. and Wiberg, D. (2015). Securing Water, Sustaining Growth: Report of the GWP/OECD Task Force on Water Security and Sustainable Growth, University of Oxford, UK, 180pp.

Sánchez-Triana, E., L, Ortolano \& Tapas Paul (2016). Managing water-related risks in the West Bengal Sundarbans: policy alternatives and institutions. International Journal of Water Resources Development, DOI: 10.1080/07900627.2016.1202099

Shameen, M.I.M., Momtaz, M. and Rauscher, R. (2014). Vulnerability of rural livelihoods to multiple stressors: A case study from the southwest coastal region of Bangladesh." Ocean \& Coastal Management, 102:79-87.

Simpson, M., R., James, J.W., Hall, E., Borgomeo, M.C., Ives, S., Almeida, A., Kingsborough, T., Economou, D., Stephenson, T., Wagener (2016). Decision Analysis for Management of Natural Hazards. Annual Review of Environment and Resources, 41, 489-516.

Sivapalan, M., and G. Blöschl (2015). Time scale interactions and the coevolution of humans and water, Water Resour. Res., 51, 6988-7022, doi:10.1002/2015WR017896.

Sivapalan, M., Savenije, H. H. G. and Blöschl, G. (2012). Socio-hydrology: A new science of people and water. Hydrol. Process., 26, 1270-1276. doi: 10.1002/hyp.8426 
Stephens, E. C. et al. (2012). Modeling the impact of natural resource-based poverty traps on food security in Kenya: the crops, livestock and soils in smallholder economic systems (CLASSES) model. Food Sec. 4, 423-439.

Szabo, S, S., Sohel, N., Adger, Z., Matthews, S., Ahmed, A., Lázár, S., Ahmad (2016). Soil salinity, household wealth and food insecurity in tropical deltas: evidence from south-west coast of Bangladesh. Sustain. Sci., 11, 3, 411-421.

Thompson, PM, P., Sultana (1996). Operation and Maintenance Performance and Conflicts in Flood-control Projects in Bangladesh, International Journal of Water Resources Development, 12, 311-328, DOI: 10.1080/07900629650196

Toufique, K. A., Islam, A. (2014). Assessing risks from climate variability and change for disaster-prone zones in Bangladesh. International Journal of Disaster Risk Reduction, 10, 236-249.

Troy, T. J., Konar, M., Srinivasan, V., and Thompson, S.(2015a). Moving sociohydrology forward: a synthesis across studies, Hydrol. Earth Syst. Sci., 19, 3667-3679, doi:10.5194/hess-19-3667-2015.

Troy, T. J., M. Pavao-Zuckerman, and T. P. Evans (2015b). Debates-Perspectives on sociohydrology: Socio-hydrologic modeling: Tradeoffs, hypothesis testing, and validation, Water Resour. Res., 51, 4806-4814, doi:10.1002/2015WR017046.

Tuong, T.P. et. al. (2014). Messages from the Ganges Basin Development Challenge: Unlocking the Production Potential of the Polders of the Coastal Zone of Bangladesh through Water Management Investment and Reform. CPWF Research for Development Series, paper 9. Dhaka, Bangladesh: CPWF. 
Turner, D. S., Richter, HE (2011). Wet/Dry Mapping: Using Citizen Scientists to Monitor the Extent of Perennial Surface Flow in Dryland Regions. Environ Manage., 47, 3, 497-505.

UNICEF (2014). Managed Aquifer Recharge (MAR): Creating Fresh Drinking Water in Brackish Aquifers. Dhaka, UNICEF Bangladesh Country Office.

Viglione, A., G. Di Baldassarre, L. Brandimarte, L. Kuil, G. Carr, J. L. Salinas, A. Scolobig, and G. Blöschl (2014). Insights from socio-hydrology modelling on dealing with flood riskRoles of collective memory, risk-taking attitude and trust, J. Hydrol., 518, 71-82, doi:10.1016/j.jhydrol.2014.01.018.

Wheater, H. S., and P. Gober (2015). Water security and the science agenda, Water Resour. Res., 51, 5406-5424, doi:10.1002/2015WR016892.

World Bank (2013). Bangladesh - First Phase of the Coastal Embankment Improvement Project. Washington DC ; World Bank.

Zaman (1983). Economic opportunities from polders in Bangladesh. International Journal of Water Resources Development, 1, 3, 197-204, DOI: 10.1080/07900628308722288 
Table 1. Typical size of land owned and average annual income for a small farmer in Bangladesh adapted from Table 4.6 in BBS (2010). Saving fraction is a model parameter.

\begin{tabular}{ccc}
\hline $\begin{array}{c}\text { Size of } \\
\text { Land } \\
\text { Owned } \\
\text { (ha) }\end{array}$ & $\begin{array}{c}\text { Average Annual } \\
\text { Income (taka) }\end{array}$ & $\begin{array}{c}\text { Saving fraction (as a \% } \\
\text { of annual income) }\end{array}$ \\
\hline $\mathbf{0 . 5}$ & 130000 & 5 \\
\hline
\end{tabular}


Table 2. Percentage of area covered by each crop, average yield, crop price and crop calendar. Data from Bangladesh Water Development Board (2012) and BBS (2013).

\begin{tabular}{lcccc}
\hline Crop & $\begin{array}{c}\text { Area } \\
\text { (\% of } \\
\text { land } \\
\text { owned) }\end{array}$ & $\begin{array}{c}\text { Average yield } \\
\text { (t/ha) }\end{array}$ & $\begin{array}{c}\text { Crop price } \\
\text { (taka/kg) }\end{array}$ & $\begin{array}{c}\text { Crop } \\
\text { calendar } \\
\text { (inclusive) }\end{array}$ \\
\hline $\begin{array}{l}\text { T. Aus (high yield } \\
\text { variety) }\end{array}$ & 0.27 & 3.8 & 17.31 & May-Aug \\
T. Aman (local variety) & 35.42 & 2.52 & 21.44 & Aug-Nov \\
T. Aman (high yield & 36.56 & 3.60 & 44.19 & Aug-Dec \\
variety) & & & & \\
Boro (hybrid) & 0.19 & 5.92 & 32.81 & Jan-May \\
$\begin{array}{l}\text { Summer Vegetables } \\
\text { (pumpkin) }\end{array}$ & 0.95 & 12 & 15.99 & Mar-July \\
Khesari (grass pea) & 23.80 & 0.75 & 51.72 & Nov-Mar \\
Mugh & 0.76 & 0.73 & 113.78 & Jan-May \\
Chili & 0.91 & 1.2 & 47.97 & Jan-Jun \\
$\begin{array}{l}\text { Sweet potato } \\
\text { Maize }\end{array}$ & 0.76 & 13.8 & 15.62 & Jan-May \\
\hline
\end{tabular}


Table 3. Parameters and state variables used in the coupled human-water dynamical model.

\begin{tabular}{|c|c|c|c|}
\hline Parameter & Definition & Unit & Value \\
\hline$\lambda$ & Average waiting time between flood events & $(-)$ & $1 / 36$ \\
\hline$\gamma$ & Damage parameter & $(-)$ & 5 \\
\hline$A_{T}$ & $\begin{array}{c}\text { Total area available for agriculture in the } \\
\text { polder }\end{array}$ & ha & 3260 \\
\hline$e_{F}$ & Environmental stress parameter & $(-)$ & 0.4 \\
\hline$q$ & Salinity intrusion parameter & $(-)$ & 0.4 \\
\hline$d_{e}$ & Water infrastructure deterioration rate & $(-)$ & 0.005 \\
\hline$I$ & Interventions to improve water infrastructure & $(-)$ & 1 \\
\hline$\beta$ & Water infrastructure damage parameter & $(-)$ & 20 \\
\hline$\varphi$ & Saving fraction & $(-)$ & See Table 1 \\
\hline $\bar{Y}_{x}$ & Average yield per hectare for crop $\mathrm{x}$ & (tonne/ha) & See Table 2 \\
\hline$s_{p}$ & Normalized salinity profile & $(-)$ & $\begin{array}{l}\text { See Lázár et al. } \\
\text { (2015) }\end{array}$ \\
\hline$p_{x}$ & Crop price for crop $\mathrm{x}$ & taka & See Table 2 \\
\hline$\delta$ & Depreciation rate of assets per year & $(-)$ & 0.1 \\
\hline $\begin{array}{c}\text { State } \\
\text { variable }\end{array}$ & Definition & Unit & Equation \\
\hline$F$ & Magnitude of flood event & $(-)$ & Poisson process \\
\hline$\tau$ & Time of occurrence of a flood & (month) & Poisson process \\
\hline$Y_{x}$ & Actual yield per hectare for crop $\mathrm{x}$ & (tonne/ha) & $(1)$ \\
\hline$P_{x}$ & Production for crop $\mathrm{x}$ & (tonne) & $(2)$ \\
\hline$\pi$ & Agricultural income & (taka) & (3) \\
\hline$A_{F}$ & $\begin{array}{l}\text { Fraction of the polder inundated during a } \\
\text { flood }\end{array}$ & $(-)$ & (4) \\
\hline$A$ & Area available for cultivation & (ha) & $(5)$ \\
\hline$s_{L}$ & Salinity levels & $(-)$ & (6) \\
\hline$e_{R}$ & Reliability of the water infrastructure & $(-)$ & (7) \\
\hline$D$ & $\begin{array}{l}\text { Damage experienced by the water } \\
\text { infrastructure following a flood }\end{array}$ & $(-)$ & (8) \\
\hline$K$ & Asset & taka & (9) \\
\hline$L$ & Extra expenditure to deal with a flood & taka & (10) \\
\hline
\end{tabular}


Table 4. A non-exhaustive list of potential data sources to inform coupled human-water system models in coastal Bangladesh and examples of previous applications in water and/or poverty studies.

\begin{tabular}{|c|c|c|}
\hline Variable & Data Source & Example application \\
\hline Flood damage & $\begin{array}{l}\text { Satellite images of nocturnal lights } \\
\text { (proxy for economic activity) }\end{array}$ & $\begin{array}{l}\text { Ceola et al. (2015); Kocornik-Mina et } \\
\text { al. (2015) }\end{array}$ \\
\hline Rainfall & $\begin{array}{l}\text { Signal level data from microwave } \\
\text { links in mobile communication } \\
\text { networks }\end{array}$ & Overeem et al. (2013) \\
\hline Water consumption & Smart water meters & Hope et al. (2012) \\
\hline Groundwater table depth & Accelerometer data from handpumps & Colchester et al. (2014) \\
\hline Phytoplankton dynamics & Citizen scientists & Castilla et al. (2015) \\
\hline $\begin{array}{l}\text { Population movement during } \\
\text { and after flood events }\end{array}$ & Mobile network data & Lu et al. (2016) \\
\hline $\begin{array}{l}\text { Change in soil water, surface } \\
\text { water and groundwater } \\
\text { storage }\end{array}$ & $\begin{array}{l}\text { Mass variability in Earth System } \\
\text { measured via NASA's Gravity and } \\
\text { Recovery and Climate Experiment } \\
\text { satellite }\end{array}$ & Richley et al. (2015) \\
\hline $\begin{array}{l}\text { Water quality and salinity } \\
\text { monitoring }\end{array}$ & Wireless Sensor Network & Corke et al. (2010) \\
\hline $\begin{array}{l}\text { Household income and asset } \\
\text { management }\end{array}$ & Financial diaries & Collins et al. (2009) \\
\hline $\begin{array}{l}\text { Welfare and economic } \\
\text { variables }\end{array}$ & Longitudinal survey & Morrow and Crivello (2015) \\
\hline
\end{tabular}




\section{List of Captions}

Figure 1. Schematic of the interactions between water-related hazards and agricultural incomes in embanked areas in coastal Bangladesh.

Figure 2. Model results under deteriorating water infrastructure and lack of maintenance. From top to bottom: time series of flood peaks, fraction of polder area flooded, monthly salinity level, embankment reliability, income. Income is measured in Bangladeshi taka (tk).

Figure 3. Income (top) and asset (bottom) for the hypothetical household under deteriorating water infrastructure and lack of maintenance. Troughs in both incomes and assets reflect abrupt losses caused by flood events. Incomes and assets are measured in Bangladeshi taka (tk).

Figure 4. Asset dynamics for the hypothetical farmer in the embanked areas. The grey line indicates a steady state of no asset accumulation. Points clustering below the grey line indicate a poverty trap situation where asset today is less than the asset yesterday. Assets are measured in Bangladeshi taka (tk).

Figure 5. Model results following improvements in water infrastructure reliability, operation and maintenance. From top to bottom: time series of flood peaks, fraction of polder area flooded, monthly salinity level, water infrastructure reliability, income. Income is measured in Bangladeshi taka (tk).

Figure 6. Income (top) and asset (bottom) for the hypothetical household under improvements in water infrastructure reliability, operation and maintenance. Troughs in both incomes and assets reflect abrupt losses caused by flood events. Incomes and assets are measured in Bangladeshi taka (tk).

Figure 7. Asset dynamics for the hypothetical farmer in the embanked areas under improvements in water infrastructure reliability, operation and maintenance. The grey line indicates a steady state of no asset accumulation. Points clustering below the grey line indicate a poverty trap situation where asset today is less than the asset yesterday. Assets are measured in Bangladeshi taka (tk). 